\section{Bisphenol A in edible part of seafood}

\author{
Adele Repossi, Federica Farabegoli, \\ Teresa Gazzotti, Elisa Zironi, \\ Giampiero Pagliuca
}

Department of Veterinary Sciences, Alma Mater Studiorum-University of Bologna, Ozzano dell'Emilia (BO), Italy

\section{Abstract}

Bisphenol A (BPA) is a man-made compound, mainly used as a monomer to produce polycarbonate (PC), epoxy resins, non-polymer additives to other plastics, which have many food related applications, such as food storage containers, tableware and internal coating of cans, as well as non-food applications such as electronic equipment, construction materials and medical devices. BPA exposure can occur when the residual monomer migrates into packaged food and beverages. Moreover, due to the ubiquitous presence of this compound, the general population can be exposed to environmental sources such as water, air and soil. Many studies have investigated the potential health hazards associated with BPA, which can elicit toxic and cancerogenic effects on humans. According to the European Food Safety Authority opinion, diet is considered to be the main source of exposure, especially canned food; moreover, among non-canned food, meat and fish products have the highest levels of BPA contamination. This review focuses on BPA contamination in seafood, analysing worldwide literature (from January 2010 to October 2015) on BPA contamination of edible parts. The authors try to identify differences between canned and non-canned seafood in literature, and gaps in the state of art. The data evaluated underline that all concentrations for both canned and non-canned seafood were below the specific migration limit set by the European Community Directive for BPA in food. Moreover, the canned seafood is more contaminated than the non-canned one.

\section{Introduction}

\section{Brief history and chemical properties}

Bisphenol A (BPA) [4,40-dihydroxy-2,2diphenylpropane] is a man-made compound, produced from the condensation of two moles of phenol and one mole of acetone (Geens et al., 2012). This monomer was first synthesized by A.P. Dianin in 1891 (Michalowicz, 2014).
BPA has a molecular weight of 228.29 and its physical state is represented by white to light brown flakes or powder (PubChem, 2015).

In 1957 the commercial production of BPA began in the United States and only one year later in Europe (Corrales et al., 2015). Since then, it has been used as a monomer to produce polycarbonate (PC), epoxy resins for coating, the flame retardant tetrabromobisphenol A, PVC stabilizers and antioxidant in the production plastics (Groshart et al., 2001).

It has a high water solubility $(120 \mathrm{mg} / \mathrm{L}$ at $25^{\circ} \mathrm{C}$ ), and according to its chemical-physical properties, it (log $\mathrm{K}_{\mathrm{OW}}$ is about 3.4 ) shows a moderate bioaccumulative potential (Corrales et al., 2015; Groshart et al., 2001). Nevertheless, recent studies focused on the bioaccumulation and toxicological properties of moderately lipophilic substances (Corrales et al., 2015).

BPA is also characterised by rapid photo-oxidation in air, which explains its short half-life in the atmosphere (0.2 days). BPA has been found in many environmental matrices (water, soil, and air), but also in humans and wildlife despite the above-mentioned half-life and the moderate potential for bioaccumulation (Corrales et al., 2015).

In 1993 a research team accidentally discovered a substance, with estrogenic properties in the yeast culture media, leached out of PC flasks during the autoclaving procedure.

After many investigations, this substance was identified as BPA (Krishnan et al., 1993), whose estrogenic properties had been acknowledged since 1930s (Dodds and Lawson, 1936). In 1995 it was reported, for the first time, that some canned food and its preserving liquid can acquire estrogenic activity: this phenomenon was reasonably attributed to BPA leached from the coating lacquer (Brotons et al., 1995). Since that moment there was an increasingly interest by scientists all over the world to further investigate the migration of this compound from packaging to canned food.

\section{Applications and exposure sources}

$\mathrm{BPA}$ is one of the highest volume chemicals manufactured globally. The worldwide production is expected to exceed 6.3 million metric tons in 2015 (Cantonwine et al., 2013). The majority of BPA is used for the production of polycarbonate plastics: due to its thermoresistance and transparency, it is used for the production of optical media, construction materials, electronic equipments, food and storage containers, tableware, reusable water bottles (Arnich et al., 2011; Geens et al., 2011; EFSA, 2015d). The second largest application is represented by epoxy resins, which perform well in terms of corrosion protection, mechanical and thermal stability. They are used in several consumer and industry applications: internal
Correspondence: Teresa Gazzotti, Laboratory of Analytical Bio-Agroalimentary Chemistry (CABALab), Department of Veterinary Sciences, Alma Mater Studiorum-University of Bologna, via Tolara di Sopra 50, 40064 Ozzano dell'Emilia (B0), Italy.

Tel. +39.051.2097012 - Fax: +39.051.2097346.

E-mail: teresa.gazzotti@unibo.it

Key words: Bisphenol A; Seafood; Endocrine disruptor.

Conflict of interest: the authors declare no potential conflict of interest.

Acknowledgments: AR acknowledges funds from MIUR Fund to Support Young Scientists, cofinanced by the Department of Veterinary Medical Sciences of the Alma Mater Studiorum-University of Bologna for a doctoral fellowship.

Received for publication: 4 December 2015. Revision received: 10 February 2016.

Accepted for publication: 10 February 2016.

This work is licensed under a Creative Commons Attribution-NonCommercial 4.0 International License (CC BY-NC 4.0).

(C) Copyright A. Repossi et al., 2016

Licensee PAGEPress, Italy

Italian Journal of Food Safety 2016; 5:5666

doi:10.4081/ijfs.2016.5666

coating of metallic food and beverage cans, pipes for drinking water and food industry, construction panels and automotive parts (Vanderberg et al., 2010; Arnich et al., 2011; Geens et al., 2011). Other polymers include for example polysulfone, which have several medical applications, and the flame retardant tetrabromobisphenol A (Geens et al., 2011).

BPA is also utilised in stabilisers and antioxidants products such as vinyl chloride, and it is also employed in thermal paper production for tickets, newspapers and food packaging (Geens et al., 2011; Michalowitz, 2014).

Due to the massive presence of its products in so many applications that can potentially release BPA, it is considered a ubiquitous environmental contaminant (Flint et al., 2012). Therefore, the environment (air, soil and water) can be a human source of exposure but the most important is the diet (Kang et al., 2006; Geens et al., 2012; EFSA, 2013). In particular, canned food is considered the major contributor for all age groups (EFSA, 2015d).

In fact, consumers may be exposed to BPA when the residual monomer in the polymer migrates from cans into food and beverages, or if the polymer itself undergoes to hydrolysis (Hoekstra and Simoneau, 2013).

In general, the migration of substances from packages into food and beverages is a complex phenomenon, influenced by different factors 
such as (Arvanitoyannis and Kotsanopoulos, 2014): food composition (foodstuff with high fat content were reported to show high migration levels); type of contact [the migration is influenced by the specific type of contact between food and packaging (direct and indirect contact)]; time of contact (the concentration of the migrating molecule in food is directly proportional to the square root of the contact time); temperature of contact (higher temperature seems to be related to an high migration rate); type of packaging material (thinner packages are linked with higher migration rates); nature and amount of migrant compound.

Dental fissure sealants, printing inks, adhesives, thermal paper, medical devices and children's toys and articles intended to be mouthed, represent other sources of consumer exposure, (Hoekstra and Simoneau, 2013; EFSA, 2015d).

\section{Bisphenol $A$ in seafood}

According to EFSA report (EFSA, 2013) fish and seafood, a relevant part of human diet, present one of the highest BPA contamination. While canned products can be contaminated through the mechanism described above, BPA may leach from plastic in oceans, causing a direct contamination of fish. Plastic debris may be the major source of BPA in seafood: this material can contain BPA at concentration up to $300 \mathrm{ppb}$. Bioaccumulation rates in fish tissues and seafood were already measured (Gatidou et al., 2010; Liu et al., 2012; Yang et al., 2014). Some researchers argue that the BPA environmental contamination in fish can be higher than in canned foods (Engler, 2012).

\section{Health effects}

BPA is considered an endocrine disrupting compound (EDC) (Rubin and Soto, 2009; Rochester, 2013), which is defined by the European Community as an exogenous substance or mixture that alters function(s) of the endocrine system.

BPA can stimulate the transcriptional activity of estrogen receptor and (ER and ER, respectively) at a concentration of 100-1000 nM. Moreover, it shows an affinity 10.000 -fold lower than estradiol (E2) for both ER and ER (Kuiper et al., 1998).

BPA completes its disrupting activity mimicking, enhancing or inhibiting the activity of endogenous estrogens, disrupting estrogen nuclear hormone receptor action (Wetherill $e t$ al., 2007). This molecule is defined as a selective estrogen receptor modulator (SERM) because it can exert estrogenic or anti-estrogenic activity in different tissues (Richter $e t$ al., 2007; Wetherill et al., 2007).

BPA can elicit adverse health effects both in humans, animals and in wildlife species (Oehlmann et al., 2009; Flint et al., 2012; Rochester, 2013); human exposure can be related to alterations in fertility, development, cardiovascular apparatus, metabolic functions and immune system (Rochester, 2013; Mileva et al., 2014). Recent studies investigated the epigenetic effects linked to this contaminant (Susiarjo et al., 2007; Singh and Li, 2012; Mileva et al., 2014). BPA exposure can alter selected gene expression through histone methylation and induce DNA methylation changes, which are altered in cancer cells (Susjario et al., 2007; Romani et al., 2015). BPA exposure studies, in developmental in vivo models, show increase susceptibility to prostate, hepatic and breast carcinogenesis (Ferreira et al., 2015; Romani et al., 2015).

BPA is considered to follow the low-dose and non-monotonic nature of hormones and endocrine disruptors: non-monotonic doseresponse curves often show a $U$ or inverted $U$ shape in a dose-response curve. The low-dose hypothesis is based on the idea that low-doses can act in a non-linear manner, and exhibit significant effects at low levels, which could not happen at higher doses (Vandenberg et al., 2012; Rochester, 2013).

This behaviour has been observed in animals, but further studies are needed to confirm it in humans.

In 2014 EFSA published Public consultation on the draft opinion on bisphenol A (BPA) Assessment of human health risks. ANSES (Agence Nationale de Sécurité Sanitaire de l'alimentation, de l'environnement et du travail) highlighted the extensive work conducted by EFSA, but identified certain differences in the evaluation and interpretation of the available studies (ANSES, 2015).

In 2015 report EFSA concluded that BPA does not present any risk for consumer health at the current exposure levels, but nonetheless updated the tolerable daily intake (TDI) from 50 to $4 \mathrm{~g} / \mathrm{kg}$ body weight per day; this value is twelve and a half times lower than the previous level (EFSA, 2015b).

This TDI is temporary (t-TDI), pending the outcome of an on-going long-term study in rats involving prenatal and postnatal exposure to BPA (EFSA, 2015c).

However, according to EFSA latest Risk Assessment (EFSA, 2015a), based on animal studies, BPA at high doses [more than 100 times the tolerable daily intake (TDI)] may cause adverse effects in liver and kidney. Moreover, possible adverse effects on nervous, immune, reproductive, cardiovascular, metabolic systems, and cancerogenicity are not considered likely at present, but they could not be excluded.

In conclusion, EFSA experts affirmed that, on the basis of the available data, there is no evidence on BPA non-monotonic doseresponse relationships for the health effects considered: BPA poses no health risk to consumers of any age group (including unborn children, infants and adolescents) at current exposure levels, from diet, dust, cosmetics and thermal papers (EFSA, 2015a).

Nevertheless, the French Agency ANSES established that BPA is not harmless. In this sense France Government decided to ban BPA in food packaging produced or imported into its territory as from 1 January 2015 (European Parliament, 2015).

In addition, the Danish National Food Institute's scientists evaluate that EFSA's new TDI does not give protection against endocrine disrupting effects: it is proposed a new TDI of $0.7 \mathrm{mg} / \mathrm{kg}$ body weight per day or lower. The institute's assessment is based on the same studies as those in the EFSA report (DTU Food, 2015).

Other non European Authorities expressed their opinion on this issue. In 2005, the Japanese Institute of Advanced Industrial Science and Technology reported BPA was unlikely to represent unacceptable risks to human health and this opinion was confirmed in 2011 (EFSA, 2015e).

In 2008 the US National Toxicology Program (NTP) expressed some concerns about BPA effects on the infants and children behaviour, on the development of prostate and brain after pre-natal and post-natal exposure at current levels of human exposure; in addition NTP assessed minimal concerns about mammary gland development, acceleration in puberty and fetal and neonatal mortality (EFSA, 2015e).

In 2014 the US Food and Drug Administration (FDA) announced the safety of BPA at the current levels occurring in foods: in addition, together with Health Canada and Food Standard Australia New Zealand, established a TDI of $50 \mathrm{mg} / \mathrm{kg}$ body weight per day (EFSA, 2015e).

\section{Legislation}

In Europe, the Commission Directive 2002/72/EC (European Commission, 2002) authorised the use of BPA as monomer and additive for the manufacture of plastic materials and articles intended to come in contact with foodstuffs, and set a specific migration limit (SML) of $0.6 \mathrm{mg}$ per kilogram food. In 2011 this Directive was amended by the Commission Directive 2011/8/EU, which posed a temporary ban on its use in manufacture of infant feeding bottles.

Then, Directive 2002/72/EC was replaced by Regulation (EU) No 10/2011 (European Commission, 2011), which maintained the ban of BPA in polycarbonate infant feeding bottles and kept the current restriction for BPA as a monomer with a specific migration limit $(\mathrm{SML})=0.6 \mathrm{mg} / \mathrm{kg}$ food, but removed it from the authorisation list as an additive in plastic food contact materials and articles.

In 2008 Canada established a ban on the use 
of BPA in polycarbonate baby bottles in order to reduce infants exposure to this contaminant (Carwile et al., 2009).

In 2010 Australian Government established a voluntary phase-out of the use of PC plastic baby bottles (Food Standards Australia New
Zealand, 2015).

\section{Analytical methods in foodstuffs}

Highly selective and sensitive techniques are required for BPA determination in foodstuffs, due to the low levels at which it can be found and the different composition of food matrices. Although the European Commission SML is set at $0.6 \mathrm{mg} / \mathrm{kg}$, analytical methods have been developed with low detection limits to better assess the human exposure (Ballesteros-Gómez et al., 2009).

Table 1. Bisphenol A mean values (expressed in $\mathrm{ppb}$ ) of canned seafood products.

\begin{tabular}{|c|c|c|c|c|c|c|c|c|}
\hline Continent & Seafood type & $\%$ Pos & $\begin{array}{l}\text { Total } \\
\text { samples }\end{array}$ & $\begin{array}{l}\text { Mean } \\
(\mathrm{ppb})\end{array}$ & $\begin{array}{l}\text { Range } \\
(\mathrm{ppb})\end{array}$ & $\begin{array}{l}\text { Origin/ } \\
\text { commercial area }\end{array}$ & Method & Authors \\
\hline America & $\begin{array}{l}\text { Tuna } \\
\text { Tuna } \\
\text { Tuna } \\
\text { Tuna } \\
\text { Tuna in oil } \\
\text { Tuna albacore } \\
\text { Mackerel } \\
\text { Boiled salmon } \\
\text { Canned fish } \\
\text { Canned fish }\end{array}$ & $\begin{array}{c}- \\
- \\
100.0 \\
- \\
- \\
- \\
- \\
0.0 \\
33.3 \\
100.0\end{array}$ & $\begin{array}{c}15 \\
5 \\
1 \\
4 \\
2 \\
4 \\
3 \\
1 \\
3 \\
52\end{array}$ & $\begin{array}{c}137.0 \\
78.6 \\
45.6 \\
11.4 \\
4.5 \\
11.5 \\
22.0 \\
0.0 \\
1.1 \\
28.0\end{array}$ & $\begin{array}{c}9.0-534.0 \\
51.0-109.0 \\
- \\
5.8-17.0 \\
- \\
11.0-13.0 \\
- \\
- \\
- \\
1.0-265.0\end{array}$ & $\begin{array}{l}\text { Canada* }^{*} \\
\text { Canada }^{\circ} \\
\text { Ecuador } \\
\text { USA }^{\circ} \\
\text { USA }^{\circ} \\
\text { USA }^{\circ} \\
\text { USA }^{\circ} \\
\text { USA* }^{*} \\
\text { USA }^{\circ} \\
\text { Canada }^{\circ}\end{array}$ & $\begin{array}{l}\text { GC-MS } \\
\text { GC-MS } \\
\text { LC-MS/MS } \\
\text { LC-MS/MS } \\
\text { LC-MS/MS } \\
\text { LC-MS/MS } \\
\text { LC-MS/MS } \\
\text { GC-MS } \\
\text { HRGC/LRMS } \\
\text { GC-MS }\end{array}$ & $\begin{array}{c}\text { Cao et al. }(2010) \\
\text { Cao et al. }(2015) \\
\text { Fattore et al. }(2015) \\
\text { Noonan et al. }(2011) \\
\text { Noonan et al. }(2011) \\
\text { Noonan et al. }(2011) \\
\text { Noonan et al. }(2011) \\
\text { Kawamura et al. (2014) } \\
\text { Lorber et al. (2015) } \\
\text { Cao and Popovic (2015) }\end{array}$ \\
\hline Europe & $\begin{array}{l}\text { Tuna in oil } \\
\text { Tuna in water } \\
\text { Tuna in vegetable oil } \\
\text { Tuna in olive oil } \\
\text { Tuna in olive oil } \\
\text { Tuna in olive oil } \\
\text { Tuna in olive oil } \\
\text { Natural tuna } \\
\text { Natural tuna } \\
\text { Salmon } \\
\text { Anchovy } \\
\text { Anchovy fillets in vegetable oil } \\
\text { Mackerel fillets in vegetable oil } \\
\text { Mackerel } \\
\text { Mussels in pickled sauce } \\
\text { Mussels } \\
\text { Cockles } \\
\text { Sardines in vegetable oil } \\
\text { Sardines in oil } \\
\text { Fish }\end{array}$ & $\begin{array}{c}100.0 \\
100.0 \\
92.3 \\
71.4 \\
80.0 \\
100.0 \\
66.7 \\
100.0 \\
66.7 \\
100.0 \\
100.0 \\
0.0 \\
100.0 \\
0.0 \\
100.0 \\
100.0 \\
100.0 \\
60.0 \\
100.0 \\
100.0\end{array}$ & $\begin{array}{l}1 \\
1 \\
13 \\
7 \\
12 \\
1 \\
3 \\
2 \\
6 \\
1 \\
1 \\
1 \\
2 \\
1 \\
1 \\
1 \\
1 \\
5 \\
1 \\
2\end{array}$ & $\begin{array}{c}169.3 \\
126.4 \\
21.2 \\
5.2 \\
62.3 \\
30.4 \\
29.3 \\
17.5 \\
35.9 \\
3.4 \\
0.9 \\
0.0 \\
21.7 \\
0.0 \\
1.4 \\
117.0 \\
182.0 \\
3.7 \\
150.0 \\
1.1\end{array}$ & $\begin{array}{c}- \\
- \\
0.2-99.9 \\
0.2-18.9 \\
1.3-132.9 \\
- \\
1.3-13.0 \\
2.2-32.8 \\
1.3-60.9 \\
- \\
- \\
- \\
- \\
- \\
- \\
- \\
- \\
0.2-8.7 \\
- \\
0.9-1.3\end{array}$ & $\begin{array}{l}\text { Belgium* } \\
\text { Belgium* } \\
\text { Portugal } \\
\text { Portugal } \\
\text { Italy }^{\circ} \\
\text { Italy } \\
\text { Spain } \\
\text { Portugal } \\
\text { Italy }^{\circ} \\
\text { Belgium* } \\
\text { Belgium* } \\
\text { Portugal } \\
\text { Portugal } \\
\text { Spain } \\
\text { Portugal } \\
\text { Spain } \\
\text { Spain } \\
\text { Portugal } \\
\text { Spain* } \\
\text { Spain }^{\circ}\end{array}$ & $\begin{array}{l}\text { GC-MS } \\
\text { GC-MS } \\
\text { GC-MS } \\
\text { GC-MS } \\
\text { LC-MS/MS } \\
\text { LC-MS/MS } \\
\text { LC-MS/MS } \\
\text { GC-MS } \\
\text { LC-MS/MS } \\
\text { GC-MS } \\
\text { GC-MS } \\
\text { GC-MS } \\
\text { GC-MS } \\
\text { LC-FL } \\
\text { GC-MS } \\
\text { LC-FL } \\
\text { LC-FL } \\
\text { GC-MS } \\
\text { GC-MS } \\
\text { GC-MS }\end{array}$ & $\begin{array}{l}\text { Geens et al. (2010) } \\
\text { Geens et al. (2010) } \\
\text { Cuhna et al. (2012) } \\
\text { Cuhna et al. (2012) } \\
\text { Fattore et al. (2015) } \\
\text { Fattore et al. (2015) } \\
\text { Fattore et al. (2015) } \\
\text { Cuhna et al. (2012) } \\
\text { Fattore et al. (2015) } \\
\text { Geens et al. (2010) } \\
\text { Geens et al. }(2010) \\
\text { Cuhna et al. }(2012) \\
\text { Cuhna et al. }(2012) \\
\text { Alabi et al. }(2014) \\
\text { Cuhna et al. }(2012) \\
\text { Alabi et al. }(2014) \\
\text { Alabi et al. (2014) } \\
\text { Cuhna et al. (2012) } \\
\text { Kawamura et al. (2014) } \\
\text { Fasano et al. (2015) }\end{array}$ \\
\hline Africa & Tuna in oil & 0.0 & 1 & 0.0 & - & Ivory Coast & LC-MS/MS & Fattore et al. (2015) \\
\hline Asia & $\begin{array}{l}\text { Tuna in oil } \\
\text { Tuna in oil } \\
\text { Tuna in oil } \\
\text { Tuna } \\
\text { Tuna } \\
\text { Boiled tuna } \\
\text { Tuna and bonito in oil } \\
\text { Bonito in oil } \\
\text { Sardine in oil } \\
\text { Boiled salmon } \\
\text { Boiled saury } \\
\text { Boiled mackerel } \\
\text { Boiled crab } \\
\text { Blue crab } \\
\text { Boiled scalloper } \\
\text { Oyster in oil }\end{array}$ & $\begin{array}{c}- \\
100.0 \\
100.0 \\
100.0 \\
100.0 \\
100.0 \\
100.0 \\
100.0 \\
100.0 \\
100.0 \\
100.0 \\
100.0 \\
100.0 \\
100.0 \\
100.0 \\
100.0\end{array}$ & $\begin{array}{l}3 \\
1 \\
1 \\
1 \\
1 \\
1 \\
1 \\
1 \\
1 \\
1 \\
1 \\
1 \\
1 \\
1 \\
1 \\
1 \\
1 \\
1\end{array}$ & $\begin{array}{c}4.3 \\
36.0 \\
120.0 \\
55.8 \\
81.1 \\
6.0 \\
56.0 \\
5.0 \\
0.0 \\
12.0 \\
0.0 \\
7.0 \\
7.0 \\
320.0 \\
21.0 \\
10.0 \\
\end{array}$ & $\begin{array}{c}0.5-13.0 \\
- \\
- \\
- \\
- \\
- \\
- \\
- \\
- \\
- \\
- \\
- \\
- \\
- \\
- \\
-\end{array}$ & $\begin{array}{l}\text { Japan } \\
\text { Thailand* } \\
\text { Vietnam* } \\
\text { Indian Ocean } \\
\text { Thailand } \\
\text { Japan } \\
\text { Thailand* } \\
\text { Japan } \\
\text { Japan } \\
\text { Japan } \\
\text { Japan } \\
\text { Japan } \\
\text { Japan } \\
\text { Thailand* } \\
\text { Japan } \\
\text { Korea* }\end{array}$ & $\begin{array}{l}\text { GC-MS } \\
\text { GC-MS } \\
\text { GC-MS } \\
\text { LC-MS/MS } \\
\text { LC-MS/MS } \\
\text { GC-MS } \\
\text { GC-MS } \\
\text { GC-MS } \\
\text { GC-MS } \\
\text { GC-MS } \\
\text { GC-MS } \\
\text { GC-MS } \\
\text { GC-MS } \\
\text { GC-MS } \\
\text { GC-MS } \\
\text { GC-MS }\end{array}$ & $\begin{array}{l}\text { Kawamura et al. (2014) } \\
\text { Kawamura et al. (2014) } \\
\text { Kawamura et al. (2014) } \\
\text { Fattore et al. (2015) } \\
\text { Fattore et al. (2015) } \\
\text { Kawamura et al. (2014) } \\
\text { Kawamura et al. (2014) } \\
\text { Kawamura et al. (2014) } \\
\text { Kawamura et al. (2014) } \\
\text { Kawamura et al. (2014) } \\
\text { Kawamura et al. (2014) } \\
\text { Kawamura et al. (2014) } \\
\text { Kawamura et al. (2014) } \\
\text { Kawamura et al. (2014) } \\
\text { Kawamura et al. (2014) } \\
\text { Kawamura et al. (2014) }\end{array}$ \\
\hline Various origin & $\begin{array}{l}\text { Natural tuna } \\
\text { Natural tuna } \\
\text { Natural tuna } \\
\text { Tuna in olive oil }\end{array}$ & $\begin{array}{c}100.0 \\
0.0 \\
100.0 \\
100.0\end{array}$ & $\begin{array}{l}1 \\
1 \\
1 \\
1\end{array}$ & $\begin{array}{c}187.0 \\
0.0 \\
38.5 \\
25.4 \\
\end{array}$ & $\begin{array}{l}- \\
- \\
- \\
-\end{array}$ & $\begin{array}{c}\text { Pacific Ocean } \\
\text { FAO } 34,47,51,57,71 \\
\text { FAO } 67,71,77,87 \\
\text { Atlantic Ocean }\end{array}$ & $\begin{array}{l}\text { LC-MS/MS } \\
\text { LC-MS/MS } \\
\text { LC-MS/MS } \\
\text { LC-MS/MS }\end{array}$ & $\begin{array}{l}\text { Fattore et al. (2015) } \\
\text { Fattore et al. (2015) } \\
\text { Fattore et al. (2015) } \\
\text { Fattore et al. (2015) }\end{array}$ \\
\hline
\end{tabular}

\% Pos, percentage of samples above LOD/ quantification; GC-MS, gas chromatography coupled with mass spectrometry; LC-MS/MS, liquid chromatography coupled with tandem mass spectrometry; HRGC-LRMS, high resolution gas chromatography/low resolution mass spectrometry; LC-FL, liquid chromatography coupled with fluorescence detection. *Domestic or imported product commercialised in the area; ${ }^{\circ}$ area of commercialisation. Mean values represent the average value for every seafood product in each article. 
The analytical methods for the determination of BPA in seafood, include liquid chromatography (LC) and gas chromatography (GC) methods coupled with various detectors.

LC offers the advantage to analyse BPA directly, while GC needs a derivatisation step, but it is characterised by higher peak resolution (Ballesteros-Gómez et al., 2009).

Fluorescence detection (FL) can be coupled with liquid chromatography, because BPA shows native fluorescence with excitation and emission wavelengths at 275 and $305 \mathrm{~nm}$, respectively (Ballesteros-Gómez et al. 2009). The technique is utilised for BPA determination in different food matrices such as beverages, vegetables, fruit and fish (Geens et al., 2010; Bemrah et al., 2014; Liao and Kannan, 2013). LC coupled with fluorescence detection (LC-FL) can be followed by confirmatory methods such as liquid chromatography coupled with mass spectrometry (LC-MS).

LC-MS and GC coupled with mass spectrometry (GC-MS) offer more attractive and more reliable methods. Sample treatment can be reduced by the use of mass spectrometry, although a good sample preparation is still necessary: LC-MS and GC-MS methods provide higher confidence in BPA identification than other methods.

GC-MS is characterised by higher resolution and lower detection limits than LC-MS for the determination of BPA in food. However, this technique is considered quite complex, due to time-consuming derivatisation step, which can introduce new sources of errors (BallesterosGómez et al., 2009).

In addition, the analytical performance of GC methods can be reduced by the presence of lipids: extensive clean-up step is required for fatty food, such as fish (Ballesteros-Gómez et al., 2009).

\section{Aim}

The purpose of this review is to investigate seafood contaminated by BPA, a relevant component of human diet, using worldwide data. This is done in order to: i) summarise the recent literature (from 2010 to present) regarding BPA contamination of seafood (canned and non-canned); ii) determine the different factors that can affect BPA seafood contamination; iii) underline the gaps and research needs about the current state of art (e.g. limited data about BPA contamination of a variety of seafood products, different geographical areas).

\section{Literature search}

A literature search was conducted using different electronic bibliographic databases (Scopus, ProQuest Biological Science
Collection, PubMed, Google Scholar): the research was performed using different key words such as bisphenol A AND fish, and further refined adding muscle AND/OR edible in case of a large number of items. The publications analysed in this review were chosen according to the following criteria: language (only scientific studies written in English); publication period (from January 2010 to October 2015); topic (were considered scientific studies investigating BPA contamination in every seafood products); sample type (only data obtained from edible part of seafood were considered). Studies that performed BPA determination in other parts of fish, such as brain, gonads and liver, were excluded. Data for composite samples, such as flavoured, cooked samples, and fish products containing everything different from water (oil or pickled sauce) were not included; geographic origin of the samples (all papers from any geographic origin, in order to have a worldwide view of BPA contamination in seafood, all papers regarding samples from any geographic origin were considered). For canned seafood, if the geographical origin was not specified, it was considered the geographical area of commercialisation.

The publications that met these criteria were further analysed to ensure that the analytical method used to obtain the data was reliable. The articles have to specify the limit of detection (LOD) and/or limit of quantification (LOQ). In addition, they have at least to declare the accuracy and/or precision. The method should be validated in seafood matrix, or at least in other food matrices. Articles that used a method validated on other matrices such as plasma, wastewater, sediments, were not included.

In order to obtain the average value for every seafood product in each article, data reported as not detected were considered equal to zero. The range was defined between LOD and the maximum level measured.

Average values reported in Tables 1 and 2 are taken from the articles, or calculated: values are expressed using one decimal figure to uniform the data. In order to calculate BPA mean value in seafood products from each continent, concentrations expressed in dry weight or lipid weight were converted in wet weight, to make data comparable.

\section{Discussion}

In Tables 1 and 2 BPA mean values (expressed in ppb) of canned and non-canned seafood products are reported. Data are grouped by continents, seafood product type, percentage of positive samples (values $>$ LOD), number of samples analysed, range (mini- mum-maximum value), country of origin or area of commercialisation, method utilised for analysis and references.

The means of BPA concentration levels reported for canned and non-canned seafood highlight a different contamination of these products: the canned food BPA levels (46.2 ppb) are higher than those non-canned (14.9 $\mathrm{ppb})$. These data seem to be in line with those reported in the EFSA report, related to European data published for the period between January 2006 and December 2012.

About the geographical distribution, the data are limited to Europe, North America and Asia: in fact there are only few data in South America (Fattore et al., 2015; Munaretto et al., 2013) and Africa (Fattore et al., 2015), and there are no data from Oceania (Tables 1 and 2). Moreover, in canned seafood products there are no remarkable differences between the BPA mean values, calculated for the different continents: $34.0 \mathrm{ppb}$ for America, $48.9 \mathrm{ppb}$ for Europe, 46.3 ppb for Asia, for Africa there is only one data available equal to zero. Instead, BPA mean values for non-canned seafood products show bigger differences: mean value of data from America (2.2 ppb) is lower than other continents, Europe and Asia with respectively 21.5 and $14.4 \mathrm{ppb}$.

The majority of canned seafood data are derived from tuna (in oil, water, vegetable oil, natural tuna, albacore) (Table 1). It is interesting to underline that a sample of blue crab from Thailand (Kawamura et al., 2014) shows the highest value $(320 \mathrm{ppb})$ of BPA concentration: this is the only data found for this product. BPA levels in canned seafood, especially the canned tuna, have been investigated, evaluating the different migration from the packaging to the solid and liquid food portions. Different authors underline that BPA would preferably be present in the solid portion of food with respect to the liquid phase (Geens et al., 2010; Fattore et al., 2015; Noonan et al., 2011).

Furthermore, BPA migration from can is related to the preservation medium: BPA levels were higher in canned tuna preserved in oil that in aqueous medium, suggesting that oil may promote BPA migration from the can lining into the food (Fattore et al., 2015). In addition, the BPA presence in aqueous medium is not relevant, while the oil show BPA contamination, even if lower than the solid food (Fattore et al., 2015).

Storage time does not show any effect in BPA migration, while can coating type, together with sterilisation conditions, seem to be the major factors (Geens et al., 2010; Fattore et al., 2015).

Very few works have studied the influence of coating type on BPA migration in canned seafood and from their results there is no evidence of clear relationships between the coating type and the level of migration (Munguia- 
Table 2. Bisphenol A mean values (expressed in $\mathrm{ppb}$ ) of non-canned seafood products.

\begin{tabular}{|c|c|c|c|c|c|c|c|c|}
\hline Continent & Seafood type & $\%$ Pos & $\begin{array}{c}\text { Total } \\
\text { samples }\end{array}$ & $\begin{array}{l}\text { Mean } \\
(\mathrm{ppb})\end{array}$ & $\begin{array}{l}\text { Range } \\
(\mathrm{ppb})\end{array}$ & $\begin{array}{c}\text { Origin/ } \\
\text { commercial area }\end{array}$ & Method & Authors \\
\hline America & $\begin{array}{l}\text { Prawn } \\
\text { Fish } \\
\text { Fish muscle } \\
\text { Fish marine } \\
\text { Shellfish } \\
\text { Freshwater } \\
\text { Tilapia } \\
\text { Striped catfish } \\
\text { Catfish }\end{array}$ & $\begin{array}{l}83.3 \\
0.0 \\
100.0 \\
100.0 \\
40.0 \\
60.0 \\
100.0 \\
0.0 \\
100.0\end{array}$ & $\begin{array}{l}6 \\
3 \\
52 \\
5 \\
5 \\
5 \\
1 \\
2 \\
2\end{array}$ & $\begin{array}{l}1.8 \\
0.0^{\circ} \\
7.3^{\circ} \\
2.0 \\
0.4 \\
1.1 \\
2.7 \\
0.0 \\
10.4\end{array}$ & $\begin{array}{c}0.0-5.5 \\
- \\
5.1-8.9^{\circ} \\
0.5-4.5 \\
0.4-1.2 \\
0.4-3.4 \\
- \\
- \\
6.2-14.5\end{array}$ & $\begin{array}{c}\text { USA } \\
\text { USA* } \\
\text { USA } \\
\text { Canada* } \\
\text { Canada* } \\
\text { Canada* } \\
\text { Brazil } \\
\text { Brazil } \\
\text { Brazil }\end{array}$ & $\begin{array}{l}\text { GC-MS } \\
\text { GC-MS } \\
\text { GC-MS } \\
\text { GC-MS } \\
\text { GC-MS } \\
\text { GC-MS } \\
\text { GC-MS } \\
\text { GC-MS } \\
\text { GC-MS }\end{array}$ & $\begin{array}{l}\text { Zuo and Zhu (2014) } \\
\text { Lorber et al. (2015) } \\
\text { Yu and Wu (2014) } \\
\text { Cao et al. (2015) } \\
\text { Cao et al. (2015) } \\
\text { Cao et al. (2015) } \\
\text { Munaretto et al. (2013) } \\
\text { Munaretto et al. (2013) } \\
\text { Munaretto et al. (2013) }\end{array}$ \\
\hline Europe & $\begin{array}{l}\text { Anchovy } \\
\text { Mediterranean mussel } \\
\text { Stripped venus } \\
\text { Bearded horse mussel } \\
\text { Mussel } \\
\text { Bivalves } \\
\text { Barbel } \\
\text { Common bream } \\
\text { White bream } \\
\text { Club } \\
\text { Fish } \\
\text { Shellfish } \\
\text { Herring } \\
\text { Flounder } \\
\text { Cod } \\
\text { Barbus graellsii } \\
\text { Cyprinus carpio } \\
\text { Luciobarbus sclateri } \\
\text { Lepomis gibbosus } \\
\text { Frozen fish } \\
\text { Caviar spread, cod roe^ }\end{array}$ & $\begin{array}{c}100.0 \\
100.0 \\
75.0 \\
100.0 \\
- \\
14.3 \\
12.5 \\
55.6 \\
40.0 \\
40.0 \\
- \\
- \\
- \\
- \\
- \\
0.0 \\
20.0 \\
20.0 \\
0.0 \\
100.0 \\
-\end{array}$ & $\begin{array}{c}1 \\
7 \\
4 \\
7 \\
10 \\
7 \\
8 \\
9 \\
5 \\
10 \\
36 \\
33 \\
10 \\
6 \\
6 \\
9 \\
15 \\
15 \\
3 \\
2 \\
2\end{array}$ & $\begin{array}{c}0.7 \\
453.6^{\circ} \\
330.8^{\circ} \\
388.5^{\circ} \\
43.3^{\circ} \\
1.6^{\circ} \\
3.2^{\circ} \\
19.8^{\circ} \\
9.6^{\circ} \\
18.6^{\circ} \\
11.9 \\
6.7^{\circ} \\
98.6^{\circ} \\
430.4^{\circ} \\
236.3^{\circ} \\
0.0^{\circ} \\
37.3^{\circ} \\
11.8^{\circ} \\
0.0^{\circ} \\
11.5 \\
20.5^{\circ}\end{array}$ & $\begin{array}{c}- \\
342.8-611.9^{\circ} \\
115.0-6263^{\circ} \\
209.2-515.2^{\circ} \\
6.8-197.2^{\circ} \\
0.9-11.2^{\circ} \\
- \\
- \\
- \\
- \\
0.1-97.9 \\
1.4-26.2^{-} \\
- \\
98.3-755.7^{\circ} \\
25.4-798.4^{\circ} \\
- \\
0.0-223.9^{\circ} \\
0.0-59.1^{\circ} \\
- \\
10.0-13.0 \\
-\end{array}$ & $\begin{array}{c}\text { Belgium* } \\
\text { Greece } \\
\text { Greece } \\
\text { Greece } \\
\text { Poland-Russia } \\
\text { Spain } \\
\text { France } \\
\text { France } \\
\text { France } \\
\text { France } \\
\text { France* } \\
\text { France* } \\
\text { Poland-Russia } \\
\text { Poland-Russia } \\
\text { Poland-Russia } \\
\text { Spain } \\
\text { Spain } \\
\text { Spain } \\
\text { Spain } \\
\text { Norway* } \\
\text { Norway* }\end{array}$ & $\begin{array}{l}\text { GC-MS } \\
\text { GC-MS } \\
\text { GC-MS } \\
\text { GC-MS } \\
\text { HPLC-FL } \\
\text { LC-MS/MS } \\
\text { LC-MS/MS } \\
\text { LC-MS/MS } \\
\text { LC-MS/MS } \\
\text { LC-MS/MS } \\
\text { GC-MS/MS } \\
\text { GC-MS/MS } \\
\text { HPLC-FL } \\
\text { HPLC-FL } \\
\text { HPLC-FL } \\
\text { LC-MS/MS } \\
\text { LC-MS/MS } \\
\text { LC-MS/MS } \\
\text { LC-MS/MS } \\
\text { LC-MS/MS } \\
\text { LC-MS/MS }\end{array}$ & $\begin{array}{c}\text { Geens et al. (2010) } \\
\text { Gatidou et al. (2010) } \\
\text { Gatidou et al. (2010) } \\
\text { Gatidou et al. (2010) } \\
\text { Staniszewska et al. (2014) } \\
\text { Salgueiro-Gonzalez et al. (2012) } \\
\text { Miège et al. (2012) } \\
\text { Miège et al. (2012) } \\
\text { Miège et al. (2012) } \\
\text { Miège et al. (2012) } \\
\text { Bemrah et al. }(2014) \\
\text { Bemrah et al. }(2014) \\
\text { Staniszewska et al. (2014) } \\
\text { Staniszewska et al. (2014) } \\
\text { Staniszewska et al. (2014) } \\
\text { Jakimska et al. (2013) } \\
\text { Jakimska et al. (2013) } \\
\text { Jakimska et al. (2013) } \\
\text { Jakimska et al. (2013) } \\
\text { Sakhi et al. (2014) } \\
\text { Sakhi et al. (2014) }\end{array}$ \\
\hline Asia & $\begin{array}{l}\text { Big head carp } \\
\text { Catfish } \\
\text { Grass carp } \\
\text { Grey mullet } \\
\text { Mandarin fish } \\
\text { Mud fish } \\
\text { Rice field eel } \\
\text { Snakehead } \\
\text { Spotted snakehead } \\
\text { Bartail flathead } \\
\text { Bigeye } \\
\text { Bleeker's gruper } \\
\text { Goldspotted rabbitfish } \\
\text { Golden threafin bream } \\
\text { Orange-spotted grouper } \\
\text { Snubose pompano } \\
\text { Tongue sole } \\
\text { Yellow croaker } \\
\text { Yellow seafin } \\
\text { Oreochromis mossanbicus and niloticus } \\
\text { Fish, shrimp, squid } \\
\text { Tilapia } \\
\text { Tilapia } \\
\text { Tilapia } \\
\text { Carp } \\
\text { Short neckled clam } \\
\text { Black seabream } \\
\text { Yellow fin seabream } \\
\text { Crucian } \\
\text { Common carp } \\
\text { Weaver } \\
\text { Bream } \\
\text { Nile tilapia } \\
\text { Springer } \\
\text { Black mullet } \\
\text { Oxeye } \\
\text { Grass carp } \\
\text { Taiwan torrent carp } \\
\text { Minnow } \\
\text { Holland's crap } \\
\text { Common carp } \\
\text { Spotted catfish } \\
\text { Striped snakehead } \\
\text { Taiwan shoveljaw carp } \\
\text { Milkfish } \\
\text { Fish, river snail, clam } \\
\end{array}$ & 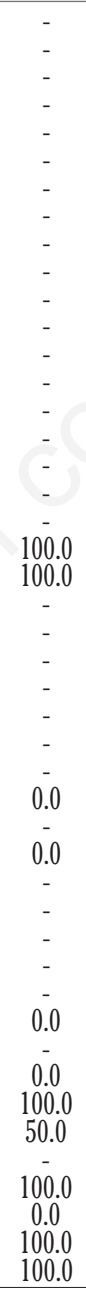 & $\begin{array}{c}6 \\
21 \\
6 \\
18 \\
3 \\
15 \\
14 \\
10 \\
10 \\
6 \\
33 \\
10 \\
15 \\
36 \\
9 \\
9 \\
27 \\
15 \\
9 \\
6 \\
11 \\
10 \\
114 \\
1 \\
380 \\
1 \\
1 \\
1 \\
1 \\
30 \\
1 \\
1 \\
24 \\
2 \\
3 \\
4 \\
1 \\
3 \\
1 \\
1 \\
2 \\
4 \\
1 \\
1 \\
1 \\
23 \\
\end{array}$ & $\begin{array}{c}1.9 \\
2.0 \\
1.3 \\
0.6 \\
1.9 \\
2.0 \\
0.5 \\
0.6 \\
1.3 \\
0.6 \\
0.7 \\
0.0 \\
0.7 \\
0.8 \\
0.7 \\
1.0 \\
1.1 \\
0.9 \\
0.5 \\
30.8 \\
14.1 \\
1.4 \\
33.6 \\
54.2^{\$} \\
23.5 \\
181.3^{\$} \\
177.4^{\$} \\
93.0^{\$} \\
0.0 \\
1.0^{\circ} \\
0.0 \\
4.0 \\
0.5 \\
0.7 \\
0.2 \\
0.4 \\
0.0 \\
0.0 \\
0.0 \\
2.3 \\
0.7 \\
6.3 \\
2.0 \\
0.0 \\
0.7 \\
\end{array}$ & 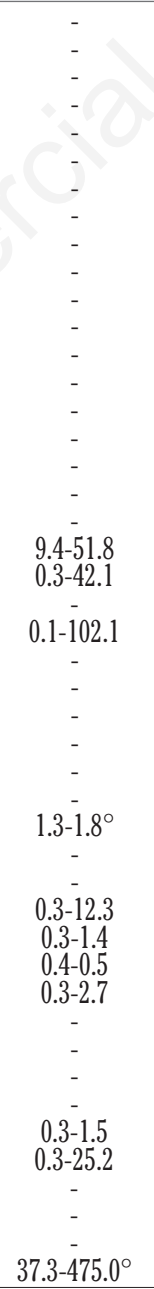 & $\begin{array}{l}\text { China } \\
\text { China } \\
\text { China } \\
\text { China } \\
\text { China } \\
\text { China } \\
\text { China } \\
\text { China } \\
\text { China } \\
\text { China } \\
\text { China } \\
\text { China } \\
\text { China } \\
\text { China } \\
\text { China } \\
\text { China } \\
\text { China } \\
\text { China } \\
\text { China } \\
\text { Taiwan } \\
\text { China } \\
\text { China } \\
\text { Taiwan } \\
\text { China } \\
\text { China } \\
\text { China } \\
\text { China } \\
\text { China } \\
\text { China } \\
\text { Iran } \\
\text { China } \\
\text { China } \\
\text { Taiwan } \\
\text { Taiwan } \\
\text { Taiwan } \\
\text { Taiwan } \\
\text { Taiwan } \\
\text { Taiwan } \\
\text { Taiwan } \\
\text { Taiwan } \\
\text { Taiwan } \\
\text { Taiwan } \\
\text { Taiwan } \\
\text { Taiwan } \\
\text { Taiwan } \\
\text { China } \\
\end{array}$ & $\begin{array}{l}\text { LC-MS/MS } \\
\text { LC-MS/MS } \\
\text { LC-MS/MS } \\
\text { LC-MS/MS } \\
\text { LC-MS/MS } \\
\text { LC-MS/MS } \\
\text { LC-MS/MS } \\
\text { LC-MS/MS } \\
\text { LC-MS/MS } \\
\text { LC-MS/MS } \\
\text { LC-MS/MS } \\
\text { LC-MS/MS } \\
\text { LC-MS/MS } \\
\text { LC-MS/MS } \\
\text { LC-MS/MS } \\
\text { LC-MS/MS } \\
\text { LC-MS/MS } \\
\text { LC-MS/MS } \\
\text { LC-MS/MS } \\
\text { LC-MS/MS } \\
\text { LC-MS/MS } \\
\text { LC-MS/MS } \\
\text { LC-MS/MS } \\
\text { GC-MS } \\
\text { GC-MS } \\
\text { GC-MS } \\
\text { GC-MS } \\
\text { GC-MS } \\
\text { HPLC-FL } \\
\text { GC-MS } \\
\text { HPLC-FL } \\
\text { HPLC-FL } \\
\text { LC-MS/MS } \\
\text { LC-MS/MS } \\
\text { LC-MS/MS } \\
\text { LC-MS/MS } \\
\text { LC-MS/MS } \\
\text { LC-MS/MS } \\
\text { LC-MS/MS } \\
\text { LC-MS/MS } \\
\text { LC-MS/MS } \\
\text { LC-MS/MS } \\
\text { LC-MS/MS } \\
\text { LC-MS/MS } \\
\text { LC-MS/MS } \\
\text { LC-MS/MS }\end{array}$ & 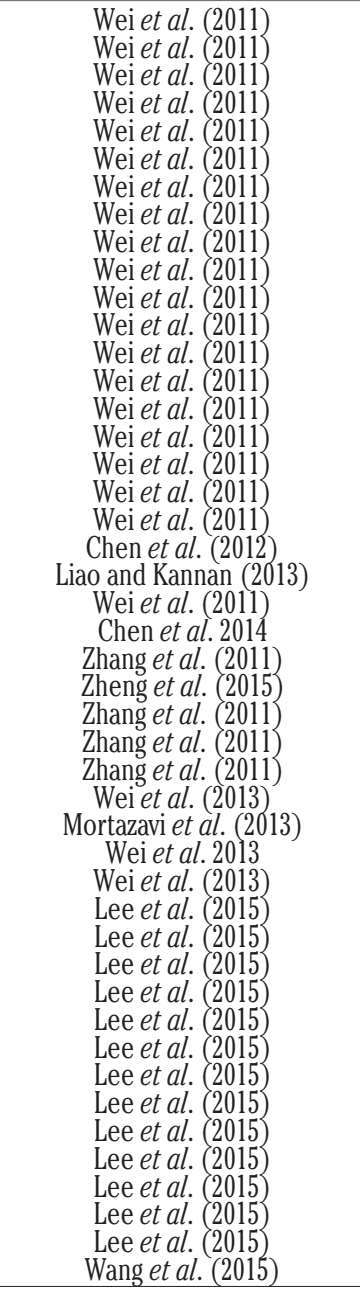 \\
\hline
\end{tabular}

$\%$ Pos, percentage of samples above limit of detection/limit of quantification; GC-MS, gas chromatography coupled with mass spectrometry; LC-MS/MS, liquid chromatography coupled with tandem mass spectrometry; HPLC-FL, high-performance liquid chromatography coupled with fluorescence detection; HRGC-LRMS, high resolution gas chromatography/low resolution mass spectrometry; LC-FL, liquid chromatography coupled with fluorescence detection. *Area of commercialisation; ${ }^{\circ}$ mean value and range expressed in dry weight; "measured limit of detection was $0.01 \mathrm{ppb} ;{ }^{8}$ product in cont
metal tube; mean value expressed in lipid weight. Mean values represent the average value for every seafood product in each article and are expressed in wet weight. 
Lopez, 2005; Geens et al., 2010). Moreover, the leaching, within the same coating type, shows great variability (Takao et al., 2002; MunguiaLopez et al., 2005).

Wei et al. (2011), on the basis of their data, reported that a relatively great BPA concentration was observed in carnivorous fish (rice field eel and yellow croaker), both of freshwater and seawater. They suggest that carnivorous fish species can accumulate more pollutants since they are at the top of the food chain.

According to Staniszewska et al. (2014), diet and habitat are the most influential factors on BPA contamination in fish tissues, together with the lipid content: the higher BPA concentrations were found in herring muscle, followed by flounder and cod.

Data collected by Staniszewska et al. (2014) showed the possible bioaccumulation BPA in the food web, specifically on lower levels of the trophic chain (zooplankton and mussels).

\section{Conclusions}

BPA contamination levels, from all data considered, for both canned and non-canned seafood, were below the specific migration limit of $0.6 \mathrm{mg} / \mathrm{kg}$ set by the EC Directive for BPA in food or food simulants. Moreover, the canned seafood is more contaminated than non-canned one. There are no differences in BPA levels found in canned food in the considered continents, while non-canned seafood products show bigger differences.

Finally, the positions of authorities on food supply chain BPA contamination are sometimes conflicting. ANSES established that BPA is not harmless, despite the reassuring EFSA report, in which a series of recommendations are pointed out in order to better characterise the risk assessment. EFSA considers that further research on the potential adverse health effects of BPA will be useful, using validated and robust methodologies (European Parliament, 2015; EFSA, 2015c).

In spite of divergences, many studies agree that there are numerous scientific uncertainties regarding assessment of BPA. The latest recommendation of 2015 EFSA report, on which ANSES agrees, claims the need to clarify the extent and the sources of unconjugated BPA in meat and fish (EFSA, 2015c).

\section{References}

Alabi A, Caballero-Casero N, Rubio S, 2014. Quick and simple sample treatment for multiresidue analysis of bisphenols, bisphenol diglycidyl ethers and their deriv- atives in canned food prior to liquid chromatography and fluorescence detection. $\mathrm{J}$ Chromatogr A 1336:23-33.

ANSES, 2015. Bisphenol A: EFSA recommends lowering the Total Daily Intake (TDI) while considering that current exposure levels are without risk for human health. Available from: http:/www.anses.fr/en/content/bisphenol-efsa-recommends-lowering-total-daily-intake-tdi-while-considering-current-exposure

Arnich N, Canivenc-Lavier MC, Kolf-Clauw M, Coffigny H, Cravedi JP, Grob K, Macherey AC, Masset D, Maximilien R, Narbonne JF, Nesslany F, Stadler J, Tulliez J, 2011. Conclusions of the French Food Safety Agency on the toxicity of bisphenol A. Int J Hyg Envir Heal 214:271-5.

Arvanitoyannis IS, Kotsanopoulos KV, 2014. Migration phenomenon in food packaging. Food-package interactions, mechanisms, types of migrants, testing and relative legislation - a review. Food Bioprocess Technol 7:21-36.

Ballesteros-Gómez A, Rubio S, Pérez-Bendito D, 2009. Analytical methods for the determination of bisphenol $\mathrm{A}$ in food. $\mathrm{J}$ Chromatogr A 1216:449-69.

Bemrah N, Jean J, Riviere G, Sanaa M, Leconte S, Bachelot M, Deceuninck Y, Le Bizec B, Dauchy X, Roudot AC, Camel V, Grob K, Feidt C, Picard-Hagen N, Badot PM, Foures F, Leblanc JC, 2014. Assessment of dietary exposure to bisphenol A in the French population with a special focus on risk characterisation for pregnant French women. Food Chem Toxicol 72:90-7.

Brotons JA, Olea-Serrano MF, Villalobos M, Pedraza V, Olea N, 1995. Xenoestrogens released from lacquer coatings in food cans. Environ Health Persp 103:608-12.

Cantonwine DE, Hauser R, Meeker JD, 2013. Bisphenol A and human reproductive health. Expert Rev Obstet Gynecol 8:32935.

Cao XL, Corriveau J, Popovic S, 2010. Bisphenol A in canned food products from Canadian markets. J Food Protect 73:10859.

Cao XL, Perez-Locas C, Robichaud A, Clement G, Popovic S, Dufresne G, Dabeka RW, 2015. Levels and temporal trend of bisphenol A in composite food samples from Canadian Total Diet Study 2008-2012. Food Addit Contam 15:1-7.

Cao XL, Popovic S, 2015. Bisphenol A and three other bisphenol analogues in canned fish products from the Canadian market 2014. J Food Protecy 78:1402-7.

Carwile JL, Luu HT, Bassett LS, Driscoll DA, Yuan C, Chang JY, Ye X, Calafat AM, Michels KB, 2009. Polycarbonate bottle use and urinary bisphenol A concentrations. Environ Health Persp 117:1368-72.
Chen WL, Gwo JC, Wang GS, Chen CY, 2014. Distribution of feminizing compounds in the aquatic environment and bioaccumulation in wild tilapia tissues. Environ Sci Pollut Res 21:11349-60.

Chen WL, Wang GS, Gwo JC, Chen CY, 2012. Ultra-high performance liquid chromatography/ tandem mass spectrometry determination of feminizing chemicals in river water, sediment and tissue pretreated using disk-type solid-phase extraction and matrix solid-phase dispersion. Talanta 89:237-45.

Corrales J, Kristofco LA, Steele WB, Yates BS, Breed CS, Williams ES, Brooks BW, 2015. Global assessment of bisphenol A in the environment review and analysis of its occurrence and bioaccumulation. Dose Response 13:1559325815598308.

Cunha SC, Cunha C, Ferreira AR, Fernandes J0, 2012. Determination of bisphenol A and bisphenol B in canned seafood combining QuEChERS extraction with dispersive liquid-liquid microextraction followed by gas chromatography-mass spectrometry. Anal Bioanal Chem 404:2453-63.

Dodds EC, Lawson W, 1936. Synthetic estrogenic agents without the phenanthrene nucleus. Nature 137:996.

DTU Food, 2015. National Food Institute maintains its assessment of bisphenol A. National Food Institute, Technical University of Denmark. Available from: http:/www.food.dtu.dk/english/News/2015/ 02/National-Food-Institute-maintains-itsassessment-of-bisphenol-A?id=1c4245aeb133-4d8b-9448-faac26ca4b9a

EFSA, 2013. DRAFT scientific opinion on the risks to public health related to the presence of bisphenol A (BPA) in foodstuffs. Available from: www.efsa.europa.eu/sites/default/files/con sultation/130725.pdf

EFSA, 2015a. No consumer health risk from bisphenol A exposure. Available from: http://www.efsa.europa.eu/en/press/news/1 50121

EFSA, 2015b. Scientific opinion on bisphenol A (2015). Available from: http://www.efsa.europa.eu/sites/default/fil es/corporate_publications/files/factsheetbpa150121.pdf

EFSA, 2015c. Scientific opinion on the risks to public health related to the presence of bisphenol A (BPA) in foodstuffs: executive summary. Available from: https://www.efsa.europa.eu/sites/default/fil es/scientific_output/files/main_documents/3978.pdf

EFSA, 2015d. Scientific opinion on the risks to public health related to the presence of bisphenol A (BPA) in foodstuffs. Part I: exposure assessment. Available from: https://www.efsa.europa.eu/sites/default/fil 
es/scientific_output/files/main_documents/3978part1.pdf

EFSA, 2015e. Scientific opinion on the risks to public health related to the presence of bisphenol A (BPA) in foodstuffs. Part II: toxicological assessment and risk characterisation. Available from: https://www.efsa.europa.eu/sites/default/fil es/scientific_output/files/main_documents/3978part2.pdf

Engler RE, 2012. The complex interaction between marine debris and toxic chemicals in the ocean. Environ Sci Technol 46:12302-15.

European Commission, 2002. Commission Directive of 6 August 2002 relating to plastic materials and articles intended to come into contact with foodstuffs, 2002/72/EC. In: Official Journal, L 220, 15/08/2002.

European Commission, 2011. Commission Directive of 14 January 2011on plastic materials and articles intended to come into contact with food, 10/2011/EU. In: Official Journal, L 12, 15/01/2011.

European Parliament, 2015. Ban on bisphenol $A$ in France. Available from: http://www.europarl.europa.eu/sides/getDo c.do?pubRef=-//EP//TEXT+WQ+E-2015002007+0+DOC+XML+V0//EN

Fasano E, Cirillo T, Esposito F, Lacorte S, 2015. Migration of monomers and plasticizers from packed foods and heated microwave foods using QuEChERS sample preparation and gas chromatography/mass spectrometry. Food Sci Technol 64:1015-21.

Fattore M, Russo G, Barbato F, Grumetto L, Albrizio S, 2015. Monitoring of bisphenols in canned tuna from Italian markets. Food Chem Toxicol 83:68-75.

Ferreira LL, Couto R, Oliveira PJ, 2015. Bisphenol A as epigenetic modulator: setting the stage for carcinogenesis? Eur J Clin Invest 45:32-6.

Flint S, Markle T, Thompson S, Wallace E, 2012. Bisphenol A exposure, effects, and policy: a wildlife perspective. J Environ Manage 104:19-34.

Food Standards Australia New Zealand, 2015. Bisphenol A (BPA). Available from: http://www.foodstandards.gov.au/consumer/chemicals/bpa/Pages/default.aspx

Gatidou G, Vassalou E, Thomaidis NS, 2010. Bioconcentration of selected endocrine disrupting compounds in the Mediterranean mussel, Mytilus galloprovincialis. Marine Pollut Bull 60:2111-6.

Geens T, Aerts D, Berthot C, Bourguignon JP, Goeyens L, Lecomte P, Maghuin-Rogister G, Pironnet AM, Pussemier L, Scippo ML, Van Loco J, Covaci A, 2012. A review of dietary and non-dietary exposure to bisphenol-A. Food Chem Toxicol 50:372540.

Geens T, Apelbaum TZ, Goeyens L, Neels H,
Covaci A, 2010. Intake of bisphenol A from canned beverages and foods on the Belgian market. Food Addit Contam A 27:1627-37.

Geens T, Goeyens L, Covaci A, 2011. Are potential sources for human exposure to bisphenol-A overlooked? Int J Hyg Envir Heal 214:339-47.

Groshart CP, Okkerman PC, Pijnenburg AMCM, 2001. Chemical study on bisphenol A. Directoraat-Generaal Rijkswaterstaat, Brussels, Belgium.

Hoekstra EJ, Simoneau C, 2013. Release of bisphenol A from polycarbonate: a review. Crit Rev Food Sci Nutr 53:386-402.

Jakimska A, Huerta B, Bargańska Z, Kot-Wasik A, Rodríguez-Mozaz S, Barceló D, 2013. Development of a liquid chromatographytandem mass spectrometry procedure for determination of endocrine disrupting compounds in fish from Mediterranean rivers. J Chromatogr A 1306:44-58.

Kang JH, Kondo F, Katayama Y, 2006. Human exposure to bisphenol A. Toxicology 226:79-89.

Kawamura Y, Etoh M, Hirakawa Y, Abe Y, Mutsuga M, 2014. Bisphenol A in domestic and imported canned foods in Japan. Food Addit Contam A 31:330-40.

Krishnan AV, Stathis P, Permuth SF, Tokes L, Feldman D, 1993. Bisphenol A: an estrogenic substance is released from polycarbonate flasks during autoclaving. Endocrinology 132:2279-86.

Kuiper GG, Lemmen JG, Carlsson B, Corton JC, Safe SH, van der Saag PT, van der Burg B, Gustafsson JA, 1998. Interaction of estrogenic chemicals and phytoestrogens with estrogen receptor beta. Endocrinology 139:4252-63.

Lee CC, Jiang LY, Kuo YL, Chen CY, Hsieh CY, Hung CF, Tien CJ, 2015. Characteristics of nonylphenol and bisphenol A accumulation by fish and implications for ecological and human health. Sci Total Environ 502:417-25.

Liao C, Kannan K, 2013. Concentrations and profiles of bisphenol A and other bisphenol analogues in foodstuffs from the United States and their implications for human exposure. J Agr Food Chem 61:4655-62.

Liu JL, Wang RM, Huang B, Lin C, Zhou JL, Pan XJ, 2012. Biological effects and bioaccumulation of steroidal and phenolic endocrine disrupting chemicals in highback crucian carp exposed to wastewater treatment plant effluents. Environ Pollut 162:325-31.

Lorber M, Schecter A, Paepke 0, Shropshire W, Christensen K, Birnbaum L, 2015. Exposure assessment of adult intake of bisphenol A (BPA) with emphasis on canned food dietary exposures. Environ Int 77:55-62.
Michalowicz J, 2014. Bisphenol A: sources, toxicity and biotransformation. Environ Toxicol Phar 37:738-58.

Miege C, Peretti A, Labadie P, Budzinski H, Le Bizec B, Vorkamp K, Tronczynski J, Persat H, Coquery M, Babut M, 2012. Occurrence of priority and emerging organic compounds in fishes from the Rhone River (France). Anal Bioanal Chem 404:2721-35.

Mileva G, Baker S, Konkle A, Bielajew C, 2014. Bisphenol-A: epigenetic reprogramming and effects on reproduction and behavior. Int J Environ Heal Res 11:7537-61.

Mortazavi S, Bakhtiari AR, Sari AE, Bahramifar N, Rahbarizadeh F, 2013. Occurrence of endocrine disruption chemicals (bisphenol a, 4-nonylphenol, and octylphenol) in muscle and liver of, Cyprinus carpino common, from Anzali Wetland, Iran. B Environ Contam Tox 90:578-84.

Munaretto JS, Ferronato G, Ribeiro LC, Martins ML, Adaime MB, Zanella R, 2013. Development of a multiresidue method for the determination of endocrine disrupters in fish fillet using gas chromatographytriple quadrupole tandem mass spectrometry. Talanta 116:827-34.

Munguia-Lopez EM, Gerardo-Lugo S, Peralta E, Bolumen S, Soto-Valdez H, 2005. Migration of bisphenol A (BPA) from can coatings into a fatty-food simulant and tuna fish. Food Addit Contam 22:892-8.

Noonan GO, Ackerman LK, Begley TH, 2011. Concentration of bisphenol A in highly consumed canned foods on the US market. J Agr Food Chem 59:7178-85.

Oehlmann J, Schulte-Oehlmann U, Kloas W, Jagnytsch 0, Lutz I, Kusk KO, Wollenberger L, Santos EM, Paull GC, Van Look KJ, Tyler CR, 2009. A critical analysis of the biological impacts of plasticizers on wildlife. Phil Trans Roy Soc B 364:2047-62.

PubChem, 2015. Bisphenol A. Available from: http://pubchem.ncbi.nlm.nih.gov/compound/Bisphenol_A

Richter CA, Birnbaum LS, Farabollini F, Newbold RR, Rubin BS, Talsness CE, Vandenbergh JG, Walser-Kuntz DR, vom Saal FS, 2007. In vivo effects of bisphenol A in laboratory rodent studies. Reprod Toxicol 24:199-224.

Rochester JR, 2013. Bisphenol A and human health: a review of the literature. Reprod Toxicol 42:132-55.

Romani M, Pistillo MP, Banelli B, 2015. Environmental epigenetics: crossroad between public health, lifestyle, and cancer prevention. Biomed Res Int 2015:587983.

Rubin BS, Soto AM, 2009. Bisphenol A: perinatal exposure and body weight. Mol Cell Endocrinol 304:55-62.

Sakhi AK, Lillegaard ITL, Voorspoels S, Carlsen MH, Løken EB, Brantsæter AL, Haugen M, 
Meltzer HM, Thomsen C, 2014. Concentrations of phthalates and bisphenol A in Norwegian foods and beverages and estimated dietary exposure in adults. Environ Int 73:259-69.

Salgueiro-González N, Turnes-Carou I, Muniategui-Lorenzo S, López-Mahía P, Prada-Rodríguez D, 2012. Fast and selective pressurized liquid extraction with simultaneous in cell clean up for the analysis of alkylphenols and bisphenol $\mathrm{A}$ in bivalve molluscs. J Chromatogr A 1270:807.

Singh S, Li SS, 2012. Epigenetic effects of environmental chemicals bisphenol $\mathrm{A}$ and phthalates. Int J Mol Sci 13:10143-53.

Staniszewska M, Falkowska L, Grabowski P, Kwasniak J, Mudrak-Cegiolka S, Reindl AR, Sokolowski A, Szumilo E, Zgrundo A, 2014. Bisphenol A, 4-Tert-Octylphenol, and 4-Nonylphenol in the Gulf of Gdansk (Southern Baltic). Arch Environ Contam Toxicol 67:335-47.

Susiarjo M, Hassold TJ, Freeman E, Hunt PA, 2007. Bisphenol A exposure in utero disrupts early oogenesis in the mouse. PLoS Genet 3:63-70.

Takao Y, Lee HC, Kohra S, Arizono K, 2002. Relase of Bisphenol A from food can lining upon heating. J Health Sci 48:331-34.

Vandenberg LN, Chauhoud I, Heindel JJ,
Padmanabhan V, Paumgartten FJ, Schoenfelder G, 2010. Urinary, circulating and tissue biomonitoring studies indicate widespread exposure to bisphenol A. Environ Health Persp 118:1055-70.

Vandenberg LN, Colborn T, Hayes TB, Heindel JJ, Jacobs DR Jr, Lee DH, Shioda T, Soto AM, Vom Saal FS, Welshons WV, Zoeller RT, Myers JP, 2012. Hormones and endocrinedisrupting chemicals: low-dose effects and nonmonotonic dose responses. Endocr Rev 33:378-455.

Wang Y, Wang 0, Hu L, Lu G, Li Y, 2015. Occurrence of estrogens in water, sediment and biota and their ecological risk in Northern Taihu Lake in China. Environ Geochem Health 37:147-56.

Wei F, Liu X, Zhai M, Cai Z, Xu G, Yang J, Du S, $\mathrm{Hu}$ Q, 2013. Molecularly imprinted nanosilica solid-phase extraction for bisphenol A in fish samples. Food Anal Methods 6:415-20.

Wei X, Huang YQ, Wong MH, Giesy JP, Wong CKC, 2011. Assessment of risk to humans of bisphenol A in marine and freshwater fish from Pearl River Delta, China. Chemosphere 85:122-8.

Wetherill YB, Akingbemi BT, Kanno J, McLachlan JA, Nadal A, Sonnenschein C, Watson CS, Zoeller RT, Belcher SM, 2007. In vitro molecular mechanisms of bisphe- nol A action. Reprod Toxicol 24:178-98.

Yang J, Li H, Ran Y, Chan K, 2014. Distribution and bioconcentration of endocrine disrupting chemicals in surface water and fish bile of the Pearl River Delta, South China. Chemosphere 107:439-46.

Yu Y, Wu L, 2014. Determination and occurrence of endocrine disrupting compounds, pharmaceuticals and personal care products in fish (Morone saxatilis). Front Environ Sci Eng 9:475-81.

Zhang X, Gao Y, Li O, Li G, Guo Q, Yan C, 2011. Estrogenic compounds and estrogenicity in surface water, sediments, and organisms from Yundang Lagoon in Xiamen, China. Arch Environ Contam Toxicol 61:93-100.

Zheng B, Liu R, Liu Y, Jin F, An L, 2015. Phenolic endocrine-disrupting chemicals and intersex in wild crucian carp from Hun River, China. Chemosphere 120:7439.

Zuo Y, Zhu Z, 2014. Simultaneous identification and quantification of 4-cumylphenol 2,4-bis-(dimethylbenzyl) phenol and bisphenol A in prawn Macrobrachium rosenbergii. Chemosphere 107:447-53. 